Keywords: Burnout; Psychological stress; Occupational health; Teachers; Prevalence.

\title{
Prevalence of burnout in a sample of Brazilian teachers
}

\section{Pedro R. Gil-Monte* \\ Mary Sandra Carlotto** \\ Sheila Gonçalves Câmara**}

* Unidad de Investigación Psicosocial de la Conducta Organizacional (UNIPSICO), University of Valencia

** Universidade Luterana do Brasil Canoas, RS.

SPAIN

BRAZIL

\begin{abstract}
Background and Objectives: Burnout is a psychological response to chronic work-related stress of an interpersonal and emotional nature. Brazilian law have already contemplated burnout syndrome as a mental and behavioural disorder related to work. The aim of this study was to identify the prevalence of burnout in a sample of Brazilian teachers.

Methods: The sample was composed of 714 teachers from 8 schools in Porto Alegre and its metropolitan area (Brazil). The levels of burnout were evaluated by the Spanish Burnout Inventory, educational version (SBI-Ed). In addition, Psychosomatic disorders were estimated by the UNIPSICO subscale.

Results: The percentage of participants who indicated high levels of burnout was $12 \%$ (Profile 1), and $5.6 \%$ fell into Profile 2 because they were affected by strong feelings of guilt. Moreover, participants with high scores on the SBI dimensions (low on Enthusiasm toward the job) scored significantly higher on psychosomatic disorders than participants with low scores.

Conclusions: Based on psychometric considerations, participants who fit Profile 2 of burnout could be considered burnout cases according to Brazilian legislation. However, using a clinical interview to make the diagnosis is recommended.
\end{abstract}

Received: 2 July 2010

Revised: 13 May 2011

Accepted: 30 May 2011 


\section{Introduction}

Workers' exposure to work stressors and the way they perceive them have played an important role in the appearance or worsening of a wide variety of health disorders, and affective responses such as burnout ${ }^{1}$. The World Health Organization considers burnout as a state of vital exhaustion (ICD-10, Z73.0). It is a risk for the worker, as it may cause physical and mental health disorders, and has already been regarded as a public health issue ${ }^{1}$.

According to the theoretical model of burnout developed by Gil-Monte ${ }^{2}$, burnout is a psychological response to chronic work-related stress of an interpersonal and emotional nature that appears in professionals in service organizations who work in direct contact with the clients or users of the organization. The main symptoms are: low enthusiasm toward the job -i.e., the individual's doesn't desire to achieve goals at work because it isn't a source of personal pleasure-, psychological exhaustion -i.e., the appearance of emotional and physical exhaustion due to the fact that at work s/he must deal daily with people who present or cause problems-, indolence -i.e., the appearance of negative attitudes of indifference and cynicism toward the organization's clients-, and feelings of guilt -i.e., the appearance of feelings of guilt for negative attitudes developed on the job, especially toward the people with whom s/he establishes work relationships-.

Burnout does not overlap with depres$\operatorname{sion}^{1,3}$. It may be a phase in the development of work-related depression ${ }^{4,5}$. Empirical research has shown that the exhaustion component of burnout is primarily positively related to depression 6,7 .

The model developed by Gil-Monte ${ }^{2}$, establishes two distinct profiles. Profile $1 \mathrm{de}-$ scribes individuals who suffer moderately from work-related stress, and it is characterized by low enthusiasm toward the job, high levels of psychological exhaustion, and indolence. Despite these problems, the individual is still able to do his or her work and does not experience strong feelings of guilt. In contrast, individuals who fall into Profile 2 are affected more intensely by the symptoms. They cannot do their jobs properly, which leads them to develop feelings of guilt. The "Spanish Burnout Inventory" (SBI) ${ }^{8,9}$ assesses these four aspects of burnout -i.e., enthusiasm toward the job, psychological exhaustion, indolence, and feelings of guilt-.

The impact of stressful factors on professions with specific work conditions involving a high degree of contact with the public has been studied in various countries and referred to as burnout, also known in Brazil as Professional Exhaustion Syndrome. Brazilian law have already contemplated burnout syndrome as a mental and behavioural disorder related to work since May $6^{\text {th }} 1999$ and its characterization is described in the health services procedures manual of the Brazilian Health Ministry ${ }^{10}$.

Burnout in teachers has received increasing attention by researchers and scholars, as its severity among teaching professionals has made teaching a profession at high risk of developing this syndrome ${ }^{11,12}$. Teachers are vulnerable to a large quantity of psychosocial stressors ${ }^{13,14}$. Apart from giving classes, teachers must perform administrative tasks, plan, retrain, guide students and assist parents. However, the teachers are excluded from institutional decisions, curriculum restructuring and rethinking the school, and they act as executors of proposals and ideas elaborated by others. A tendency toward individualist work is thus established, which does not allow teachers to confront and transform structural aspects of their 
work. This intensification of the teaching activity produces conflicts (e.g., students with behavioural problems, problems in the parent-teacher relationship, conflicts in cooperating with colleagues) $)^{14,15}$.

The occurrence of burnout in teachers affects the educational environment and interferes with reaching pedagogical objectives, leading professionals to a process of alienation, cynicism, apathy, health problems, and the intention to abandon the profession ${ }^{16}$.

According to estimations by Shirom ${ }^{17}$, the prevalence of burnout in teachers can be situated between $10 \%$ and $30 \%$. Unda et al. ${ }^{18}$ concluded that the prevalence of burnout in a sample of Mexican teachers was $17 \%$, and Farber ${ }^{19}$ estimated that $5 \%$ to $20 \%$ of American teachers are truly burned out. Figueredo-Ferraz et al..$^{20}$ found $14.20 \%$ of 211 Portuguese teachers in Profile 1, and only $1.9 \%$ in Profile 2. According to Trigo et al. ${ }^{21}$, in Brazil the literature found in the database utilized is scarce with regard to burnout and its prevalence. Thus, it becomes relevant to perform studies that may help to diagnose, intervene in, and prevent this occupational pathology.

The purpose of the present study is to identify the prevalence of burnout in a sample of Brazilian teachers.

\section{Method}

\section{Participants}

The study sample was composed of 714 teachers at all teaching levels from 8 schools in Porto Alegre and its metropolitan area (Brazil); overall response rate was $87.50 \%$. Regarding gender, $82.1 \%$ of the participants were women $(n=586)$, and $16.10 \%$ were men $(\mathrm{n}=115)$; the mean age was 39.32 years $(S D=10.46)$. Most participants had graduate and postgraduate education degrees $(89.4 \%)$ and worked in public institutions $(63.50 \%)$.

\section{Instruments}

The burnout levels were evaluated with a Portuguese version of the Spanish Burnout Inventory, Education professionals version (SBI-Ed) ${ }^{8}$. This instrument contains 20 items distributed into four dimensions called: Enthusiasm toward the job (5 items, alpha = 0.83), Psychological exhaustion (4 items, alpha $=0.80)$, Indolence $(6$ items, alpha $=$ $0.80)$ and Guilt (5 items, alpha $=0.82)$. The Cronbachs alpha of the 15 items (Profile 1) (SBI global score) related to Enthusiasm toward the job (reversed), Psychological exhaustion, and Indolence was 0.87 . Items were answered on a five-point frequency scale, ranging from 0 (Never) to 4 (Very frequently: every day). Low scores on Enthusiasm toward the job, together with high scores on Psychological exhaustion and Indolence, as well as on Guilt, indicate high levels of burnout ${ }^{2}$.

\section{Procedures}

For data collection, contact was first made with the administration of the teaching institutions, and the aim of the study was presented in order to obtain authorization and support for applying the instruments. The instruments were handed to the teachers personally. The ethical procedures were carried out according to resolution 196 of the National Health Council $(\mathrm{NHC})^{22}$. Teachers and principals of the teaching institutions were informed about the research, which would not have any individual and/or insti- 
tutional assessment effects, and the answers would be anonymous and confidential.

The database was analyzed by SPSS 17 . The analysis of burnout prevalence in the participants observed the reference points of the five-point frequency scale with which the participants rated each item. The cut-off established, 2 "Sometimes: a few times a month", is based on studies carried out by Gil-Monte et al. $^{23}$, and on Shirom ${ }^{17}$ 's recommendation. According to the authors, the minimum level corresponds to the appear- ance of sporadic symptoms, and the maximum level would be related to the daily and permanent presence of these symptoms in the individual's life.

\section{Results}

Table 1 shows the means, standard deviations, and internal consistencies of all the scales included in this study.

Table 1

Means, standard deviations, and internal consistencies of the SBI-Ed scales

\begin{tabular}{lccc} 
Variables & $\mathrm{M}(\mathrm{SD})$ & Range & alpha \\
\hline Enthusiasm toward the job & $3.01(0.80)$ & $0-4$ & 0.83 \\
Psychological exhaustion & $1.63(0.89)$ & $0-4$ & 0.80 \\
Indolence & $1.00(0.74)$ & $0-4$ & 0.80 \\
Guilt & $1.11(0.77)$ & $0-4$ & 0.82 \\
Burnout (SBI-Ed scale, Profile 1) & $1.17(0.64)$ & $0-4$ & 0.75 \\
Psychosomatic disorders & $1.37(0.92)$ & $0-4$ & 0.89
\end{tabular}

By considering the total score on the SBIEd scale -i.e., mean of 15 items-, the percentage of participants who indicated high levels of burnout, according to the adopted criterion, was $12 \%(\mathrm{n}=86)$ (Profile 1$)$, and $5.6 \%(\mathrm{n}=40)$ of them presented scores equal to or higher than 2 on the Guilt dimension (Profile 2).
The results revealed that $10.4 \%(n=74)$ of the participants presented levels of Enthusiasm toward the job with a frequency lower than 2. On the other hand, $36.7 \%(\mathrm{n}=$ 262) of the participants indicated high levels of Psychological exhaustion, $12.5 \%$ ( $\mathrm{n}=$ 89) presented high levels of Indolence, and $16.1 \%(\mathrm{n}=115)$ showed high feelings of Guilt (values $\geq 2$ ) (Table 2). 
Table 2

Number and percentage of participants in high vs. low levels in the SBI dimensions and global score (Profile 1)

\begin{tabular}{lcc} 
Variables & Low levels $(<2)$ & High levels $(\geq 2)$ \\
\hline Enthusiasm toward the job & $74(10.4 \%)$ & $640(89.6 \%)$ \\
Psychological exhaustion & $452(63.3 \%)$ & $262(36.7 \%)$ \\
Indolence & $625(87.5 \%)$ & $89(12.5 \%)$ \\
Guilt & $599(83.9 \%)$ & $115(16.1 \%)$ \\
Profile 1 (Mean 15 items) & $628(88.0 \%)$ & $86(12.0 \%)$ \\
Profile 2 & $674(94.4 \%)$ & $40(5.6 \%)$ \\
\hline
\end{tabular}

Note. In Profile 1, participants in the category "High levels" obtained values $\geq 2$ on the mean of the 15 items from the subscales of Enthusiasm toward the job (reversed) (5 items), Psychological exhaustion (4 items), and Indolence (6 items). In Profile 2, participants in the category "High levels" meet the criteria of obtaining values $\geq 2$ on the mean of the 15 items together with values $\geq 2$ on the Guilt subscale.

\section{Discussion and conclusions}

The purpose of this study was to identify the prevalence of burnout and to analyze its influence on levels of psychosomatic disorders in a sample of Brazilian teachers, according to the SBI theoretical model.

We found that $12 \%(n=86)$ of the participants fit Profile 1 burnout-i.e., they were affected by the syndrome, but did not present high levels of guilt. Only $5.6 \%$ of the sample $(n=40)$ fit Profile 2 -i.e., they were affected by the syndrome, and presented strong feelings of guilt. Based on psychometric considerations, these 40 cases identified as Profile 2 could be considered as burnout cases according to Brazilian legislation. However, it is recommended that the diagnosis be associated with a clinical interview because the cut-off point (i.e., values $\geq 2$ ) has not been clinically derived in samples of workers who seek psychological treatment.

Our Profile 1 results are similar to those from the study by Gil-Monte et al. ${ }^{23}$ with professionals working with psychologically disabled people, where $11.7 \%$ of participants appeared in this profile. However, the present study showed a Profile 2 prevalence higher than in the work by Gil-Monte et $a l .^{23}$, which found $1.30 \%$ of the participants in this profile. On the other hand, the results of this study are lower than the prevalence levels obtained by Unda et al. ${ }^{18}$ with a sample of Mexican teachers (Profile 1, $35.5 \%$; and Profile 2, $17.2 \%$ ). They are similar, though, to the prevalence levels found by Figueredo-Ferraz et al. ${ }^{20}$, with $14.2 \%$ of 211 Portuguese teachers in Profile 1 and $1.9 \%$ in Profile 2. These results may be related to fairly differentiated cultural and organizational aspects ${ }^{24,25}$, or they may be attributed to differences in the selection of the samples.

Taking into consideration the prevalence in the SBI dimensions, mention should be made of the high percentage of participants presenting high levels of Psychological exhaustion $(36.7 \%)$ compared to the percentages obtained in other SBI-Ed dimensions and the total scale. This result may be understood based on the high level of emotional demands teaching makes, which may indicate a tendency for more cases to appear after a longer period of exposure to stressors. 
Burnout presents degrees of the frequency and intensity of its symptoms. The percentage of workers included in the established profiles is worrisome. According to Maslach and Goldberg ${ }^{26}$, although many people may leave work as a consequence of burnout, others may stay, although working below their potential and offering low quality service in their job. Being affected by burnout may also be a reason to stay in a job, as the worker with high levels of these symptoms may feel overwhelmed and, therefore, opt not to change, since it would mean dealing with an additional stress that $\mathrm{s} /$ he does not feel capable of handling.

The results obtained are a cause for concern, considering that teachers identified as affected by burnout have been engaged in full professional activity, probably aggravating their situation and seriously damaging the quality of their work and the teaching-learning relationship. High quality work requires time and effort, commitment and creativity, but the worker in this situation does not wish to offer them spontaneously anymore. Moreover, there may be comorbidity with some mental and behavioural disorders, or it may even produce them, such as burnout followed by depressive symptoms $^{21}$. These differences in the development of burnout could be identified taking into consideration the differences between Profile 2 vs. Profile 1 offered by the SBI.

Among the limitations of the study, it must be pointed out that data were collected by means of questionnaires in a non-random way, and the sample may not be representative of the population. As is the case with any survey, there is an inherent selection bias in those electing to complete the survey. Perhaps, exhausted teachers participated in the study in order to draw attention to their inadequate job conditions. As a result, prevalence rate could be higher than in the population. On the contrary, results may be affected by the "healthy worker effect": the favorable health status of employed populations in comparison to that of the general population. The majority of the studies on burnout collected data in organizations in a non-random way, which implies that the people affected by burnout probably did not answer the questionnaire, and normative working samples will probably show relatively low levels of burnout. As a result, both morbidity and mortality rates within the workforce are usually lower than in the general population ${ }^{27}$. To establish the prevalence of burnout it would be advisable in future studies to use multi-method measures and complement the results obtained with clinical interviews with people identified as possible clinical cases.

The results deserve attention due to the high percentage obtained, if we consider that, according to data from the Brazilian Health Ministry $^{28}$, the rate of incidence of work-related diseases has been increasing in recent years $(2003=8.8 \% ; 2004=10.5 \% ; 2005=$ $12.3 \%)$. In 2005, the state of Rio Grande do Sul presented a rate of $14.74 \%$. These percentages tend to be larger in reality, due to the under-notification of occupational diseases in Brazil ${ }^{29,30}$ and lack of knowledge about the diagnosis of work-related mental diseases. According to Owens ${ }^{31}$, there is a habit of considering work leaves as medical problems, because physical demands are more easily defined and measured than mental ones. Work-related psychological disorders frequently are not recognized as such at the time of clinical evaluation. However, not recognizing the role of work in aggravating or producing psychological disorders has caused damage, not only in terms of treatment quality and efficacy, but also to the legal rights of the worker, who no longer enjoys social security benefits to which he is entitled. 


\section{References}

1. Melamed S, Shirom A, Toker S, Berliner S, Shapira I. Burnout and risk of cardiovascular disease: evidence, possible causal paths, and promising research directions. Psychol Bull 2006; 132: 327-353.

2. Gil-Monte PR. El síndrome de quemarse por el trabajo ("burnout"). Una enfermedad laboral en la sociedad del bienestar. Madrid: Pirámide; 2005.

3. Leiter MP, Durup J. The discriminant validity of burnout and depression: A confirmatory factor analytic study. Anxiety Stress Coping 1994; 7: 357-373.

4. Ahola K, Hakanen J. Job strain, burnout, and depressive symptoms: A prospective study among dentists. J Affect Disord 2007; 104: 103-110.

5. Gil-Monte PR. The influence of guilt on the relationship between burnout and depression. Eur Psychol 2011;in press. doi: 10.1027/1016-9040/a000096

6. Truzzi A, Souza W, Bucasio E, Berger W, Figueira I, Engelhardt E, et al. Burnout in a sample of Alzheimer's disease caregivers in Brazil. Eur J Psychiat 2008; 22: 151-160.

7. Pomaki G, Maes S, Doest L. Work conditions and employees' self-set goals: Goal processes enhance prediction of psychological distress and well-being. Pers Soc Psychol Bull 2004; 30: 685-694.

8. Gil-Monte PR, Carlotto MS, Câmara S. Validation of the Brazilian version of the "Spanish Burnout Inventory" in teachers. Rev Saúde Pública 2010; 44: 140-147.

9. Gil-Monte PR, Unda S, Sandoval JI. Validez factorial del "Cuestionario para la Evaluación del Síndrome de Quemarse por el Trabajo" (CESQT) en una muestra de maestros mexicanos. Salud Mental 2009; 32: 205-214.

10. Ministério da Saúde. Doenças relacionadas ao trabalho. Manual de procedimentos para os serviços de saúde. Brasília: Ministério da Saúde do Brasil; 2001. http://dtr 2001.saude.gov.br/editora/produtos/livros/pdf/02_0388_ M1.pdf (accessed April 30, 2011)

11. Stoeber J, Rennert D. Perfectionism in school teachers: Relations with stress appraisals, coping styles, and burnout. Anxiety Stress Coping 2008; 21: 37-53.

12. Skaalvik EM, Skaalvik S. Does school context matter? Relations with teacher burnout and job satisfaction. Teach Teach Educ 2009; 25: 518-524.

13. Vandenberghe R, Huberman AM, editors. Understanding and preventing teacher burnout: A sourcebook of international research and practice. Cambridge: Cambridge University Press; 1999.
14. Montgomery C, Rupp AA. A meta-analysis for exploring the diverse causes and effects of stress in teachers. Can J Educ 2005;28: 458-486.

15. Skaalvik, EM, Skaalvik S. Dimensions of teacher self-efficacy and relations with strain factors, perceived collective teacher efficacy, and teacher burnout. J Educ Psychol 2007; 99: 611-625.

16. Gil-Monte PR. A case of teacher burnout. In: Houdmont J, Leka S, editors. Occupational Health Psychology. European perspectives on research, education and practice. Nottingham: Nottingham University Press; 2008. p. 257-280.

17. Shirom A. Burnout in work organizations. In: Cooper CL, Robertson I, editors. International Review of Industrial and Organizational Psychology. New York: Wiley \& Sons; 1989. p. 25-48.

18. Unda S, Sandoval JI, Gil-Monte PR. Prevalencia del síndrome de quemarse por el trabajo (SQT) (burnout) en maestros mexicanos. Inf Psicol 2007/2008; 91/92: 53-63.

19. Farber BA. Crisis in education: stress and burnout in the American teacher. San Francisco (CA): Jossey-Bass; 1991.

20. Figueiredo-Ferraz H, Gil-Monte PR, Grau E. Prevalencia del síndrome de quemarse por el trabajo (burnout) en una muestra de maestros portugueses. Aletheia 2009; 29: 6-15.

21. Trigo TR, Teng CT, Hallak JE. Síndrome de burnout ou estafa profissional e os transtornos psiquiátricos. Rev Psiq Clín 2007; 34: 223-233.

22. Ministério da Saúde. Conselho Nacional de Saúde. Diretrizes e normas para pesquisa envolvendo seres humanos. Resolução CNS 196/196. Brasília: Ministério da Saúde do Brasil; 1997.

23. Gil-Monte PR, Carretero N, Roldán MD, NuñezRomán E. Prevalencia del síndrome de quemarse por el trabajo (burnout) en monitores de taller para personas con discapacidad. Rev Psicol Trab Organ 2005; 21: 107-123.

24. Golembiewski RT, Scherb K, Boudreau A. Burnout in cross-national settings: Generic and model-specific perspectives. In: Schaufeli WB, Maslach C, Marek T, editors. Professional burnout: Recent developments in theory and research. London: Taylor \& Francis; 1993. p. 217-236.

25. Maslach C, Schaufeli WB, Leiter MP. Job burnout. Annu Rev Psychol 2001; 52: 397422.

26. Maslach C, Goldberg J. Prevention of burnout: News perspectives. Appl Prev Psychol 1998; 7: 63-74.

27. Li CY, Sung EC. A review of the healthy worker effect in occupational epidemiology. Occup Med 1999; 49: 225-229. 


\section{PEDRO R. GIL-MONTE, MARY SANDRA CARLOTTO AND SHEILA GONÇALVES CÂMARA}

28. Ministério da Saúde. REDE Interagencial de Informação para a Saúde. Indicadores básicos para a saúde no Brasil: conceitos e aplicações. 2nd ed. Brasília: Organização Pan-Americana da Saúde; 2008.

29. Rêgo MA. Acidentes e doenças do trabalho no Estado da Bahia, de 1970 a 1992. Rev Bras Saúde Ocup 1994; 22: 21-31.

30. Salim CA. Doenças do trabalho: exclusão, segregação e relações de gênero. Sao Paulo Perspect 2003; 17: 11-24.
31. Owens P. Mental health: understanding work disability. Health Insur Underwrit 1997; 45: 12-15.

Author for correspondence:

Pedro R. Gil-Monte

Faculty of Psychology

Av. Blasco Ibáñez, 21

46010 Valencia (Spain)

Tel. +34-963 864564

E-mail: Pedro.Gil-Monte@uv.es 